Primljen / Received: 29.5.2016. Ispravljen / Corrected: 27.9.2016.

Prihvaćen / Accepted: 24.2.2017. Dostupno online / Available online: 10.2.2018.

\section{Excess pore pressure generation and post-cyclic loading settlement of geofiber-reinforced sand}

Authors:

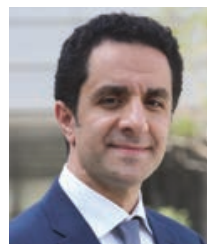

Assoc.Prof. Kenan Hazirbaba, PhD. PE American University of Ras Al Khaimah Ras Al Khaimah, UAE

Civil and Infrastructure Engineering kenan.hazirbaba@aurak.ac.ae

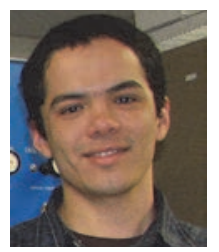

Maksat Omarow, MSc.

University of Alaska, USA

Civil and Environmental Engineering maksatomar@gmail.com
Scientific Research Paper

\section{Kenan Hazirbaba, Maksat Omarow}

Excess pore pressure generation and post-cyclic loading settlement of geofiber-reinforced sand

The response of geofibre-reinforced sand to dynamic loading is investigated in this paper in terms of excess pore pressure generation and post-cyclic load reconsolidation. Strain-controlled, undrained triaxial tests were performed on saturated sand specimens prepared with varying geofibre content. Tape type and fibrillated type polypropylene geofibre were used with Ottawa (C-109) sand at $0.2 \%$, $0.5 \%$ and $1 \%$ dosages by dry weight of soil. The tape type geofibre was found to be more effective than the fibrillated type in reducing the excess pore pressure. Both the type and content of geofibre were found to influence the post-loading settlement.

\section{Key words:}

polymer fibre reinforced sand, excess pore pressure, cyclic loading, liquefaction, volumetric strain

Prethodno priopćenje

Kenan Hazirbaba, Maksat Omarow

\section{Odgovor pijeska ojačanog polimernim vlaknima na dinamičko opterećenje}

U radu je ispitan odgovor pijeska ojačanog polimernim vlaknima na dinamičko opterećenje s aspekta generiranja dodatnog pornog tlaka i ponovne konsolidacije uslijed cikličnog opterećenja. Provedena su nedrenirana troosna ispitivanja s kontroliranom deformacijom na saturiranim pješčanim uzorcima pripremljenima s različitim udjelom polimernih vlakana. Vrpčasta vlakna i fibrilirana polipropilenska vlakna korištena su s Ottawa pijeskom (C-109) s 0,2 \%, 0,5\% i 1 \% udjela vlakana u suhoj masi tla. Ustanovljeno je da su vrpčasta vlakna učinkovitija od fibriliranih vlakana u smanjenju dodatnog pornog tlaka.

Ključne riječi:

pijesak ojačan polimernim vlaknima, dodatni porni tlak, ciklično opterećenje, likvefakcija, volumna deformacija

Vorherige Mitteilung

Kenan Hazirbaba, Maksat Omarow

\section{Reaktion des sandes mit polymerverstärkten fasern auf dynamische belastung}

In der Abhandlung wurde die Reaktion des Sandes mit polymerverstärkten Fasern auf dynamische Belastung unter dem Gesichtspunkt der Erzeugung zusätzlichen Porenwasserdrucks und der erneuten Konsolidierung aufgrund einer zyklischen Belastung untersucht. Durchgeführt wurden nicht drainierte dreiachsige Untersuchungen mit kontrollierter Verformung auf saturierten Sandproben, die mit verschiedenen Anteilen an Polymerfasern vorbereitet wurden. Die Bandfasern und fibrillierten Polypropylenfasern wurden mit Ottawa-Sand (C-109) mit einem 0,2\%, 0,5\% und 1\% Fasergehalt in trockener Bodenmasse verwendet. Es wurde festgestellt, dass die Bandfasern bei der Verringerung des zusätzlichen Porenwasserdrucks wirksamer sind, als die fibrillierten Fasern.

Schlüsselwörter:

polymerfaserverstärkter Sand, zusätzlicher Porenwasserdruck, zyklische Belastung, Verflüssigung, Volumenverformung 


\section{Introduction}

Reinforcing soils with randomly distributed geofibres has become common for various geotechnical and geoenvironmental projects, such as earth retaining structures, embankments and slopes including steep landfill covers, and subgrade stabilization, mainly due to its effectiveness and feasibility. Many studies have shown increased overall strength of soils mixed with geofibres under static loading conditions [1-7]. However, there have been few research efforts focusing on the dynamic response of geofibrereinforced sand. Noorany and Uzdavines [8] conducted stresscontrolled cyclic triaxial tests on saturated specimens of geofibre-reinforced sand and unreinforced sand, and showed that cyclic resistance of reinforced specimens was higher than that of unreinforced sand. Maher and Woods [9] reported that the dynamic shear modulus and damping capacity of sand improve with the inclusion of geofibres. The current study focuses on the generation and dissipation of excess pore pressure in geofibre-reinforced sand. Specifically, two aspects are investigated:

- whether the inclusion of geofibre can limit generation of excess pore pressure

- if the post-cyclic loading settlement due to pore pressure dissipation is affected by the reinforcement.

The generation of excess pore pressure is mainly controlled by the level of induced shear strain [10]. Thus, the experimental investigation consisted of a series of strain-controlled, undrained, cyclic triaxial tests on clean sand specimens and geofibre-reinforced sand specimens.

\section{Experimental program}

\subsection{Materials}

The soil investigated in this study is a commercially produced clean sand, known as Ottawa sand (C-109). Basic index properties of the soil are given in Table 1 and the particle size distribution is shown in Figure 1. Two types of $51-\mathrm{mm}$ long polypropylene geofibres were tested:

- fibrillated type

- tape type (Figure 2).

Polypropylene geofibre was chosen because of its availability, resistance to ultraviolet degradation, chemical stability, and reasonably high strength characteristics [7]. The index properties of the geofibres used are listed in Table 2 . The geofibre contents investigated were: $0.0 \%$ (unreinforced-clean sand), $0.2 \%, 0.5 \%$, and $1.0 \%$ by dry weight of the soil sample. The dosage in this study was limited to $1.0 \%$ due to greater cost of geofibre at higher dosages. The index properties of sand-geofibre mixtures are presented in Table 3.
Table 1. Index properties of clean Ottawa sand

\begin{tabular}{|c|c|}
\hline \multicolumn{2}{|c|}{ Ottawa sand (C-109) } \\
\hline Specific gravity & 2.66 \\
\hline Maximum void ratio & 0.78 \\
\hline Minimum void ratio & 0.48 \\
\hline$D_{10}[\mathrm{~mm}]$ & 0.25 \\
\hline $\mathrm{D}_{30}[\mathrm{~mm}]$ & 0.36 \\
\hline $\mathrm{D}_{60}[\mathrm{~mm}]$ & 0.45 \\
\hline $\mathrm{C}_{\mathrm{u}}$ & 1.8 \\
\hline $\mathrm{C}_{\mathrm{c}}$ & 1.15 \\
\hline USCS soil classification & $\mathrm{SP}$ \\
\hline
\end{tabular}

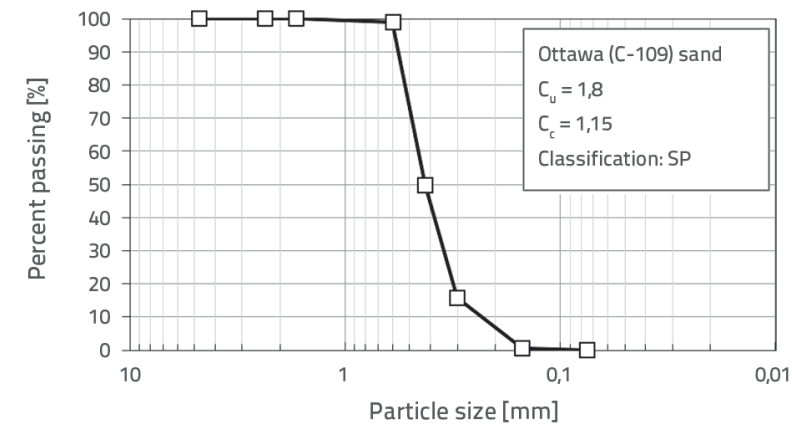

Figure 1. Grain size distribution curve of sand used in this study

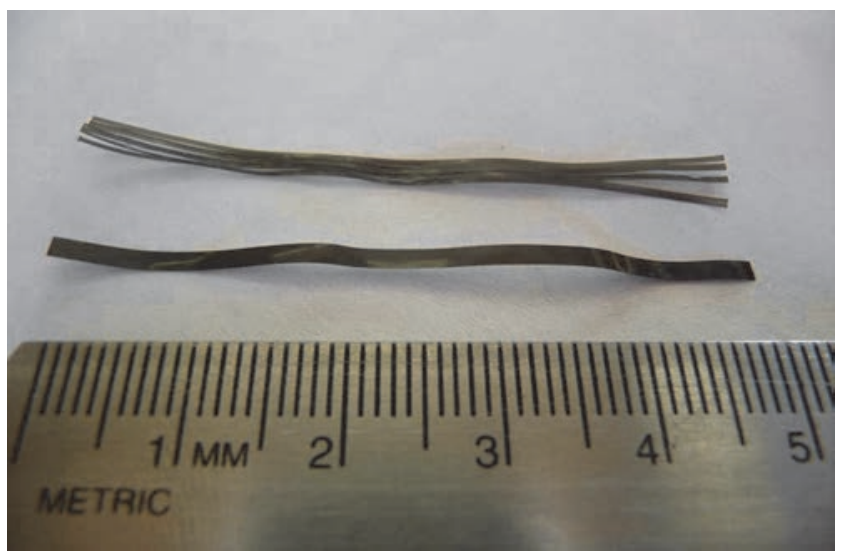

Figure 2. Photograph of geofibres used in this study

Table 2. Summary of geofibre properties

\begin{tabular}{|c|c|}
\hline Property & Value \\
\hline Polypropylene & $99.40 \%$ \\
\hline Moisture absorption & 0.0 \\
\hline Fibre length & $5.08 \mathrm{~cm}$ \\
\hline Color & $0.91 \mathrm{~g} / \mathrm{cm}^{3}$ \\
\hline Specific gravity & $0.60 \%$ \\
\hline Carbon black content & $310 \mathrm{MPa}$ \\
\hline Tensile strength & $15 \%$ \\
\hline Tensile elongation & $4800 \mathrm{MPa}$ \\
\hline Young's modulus & \\
\hline
\end{tabular}


Table 3. Index properties of sand-geofibre mixtures

\begin{tabular}{|c|c|c|c|c|c|c|}
\hline \multirow{2}{*}{ Geofibre type } & \multicolumn{3}{|c|}{ Tape } & \multicolumn{3}{c|}{ Fibrillated } \\
\cline { 2 - 7 } & $\mathbf{0 . 2}$ & $\mathbf{0 . 5}$ & $\mathbf{1 . 0}$ & $\mathbf{0 . 2}$ & $\mathbf{0 . 5}$ & $\mathbf{1 . 0}$ \\
\hline Geofibre content, $\mathbf{f}[\%]$ & 2.65 & 2.64 & 2.61 & 2.65 & 2.64 & 2.61 \\
\hline Minimum void ratio, $e_{\min }$ & 0.54 & 0.55 & 0.53 & 0.53 & 0.54 & 0.57 \\
\hline Maximum void ratio, $e_{\max }$ & 0.70 & 0.75 & 0.89 & 0.73 & 0.78 & 0.94 \\
\hline
\end{tabular}

\subsection{Cyclic triaxial testing equipment}

The experimental set-up is the same as that presented in Hazirbaba and Omarow [12]. A state-of-the-art cyclic triaxial testing equipment was used in this research. The custommade triaxial apparatus has a tilting frame that allows for in-place specimen preparation. This unique feature helps obtaining high quality specimens and thus more reliable testing results. A photograph of the system used is shown in Figure 3. The system is equipped with signal conditioning, servo amplifier, computer interface, and data acquisition units. Normal loading, cell pressure application, and back-pressure saturation, are controlled through servo pressure regulators. The triaxial cell accepts $101.6 \mathrm{~mm}$ (or smaller) diameter specimens.

\subsection{Preparation of soil specimens}

In this study, the moist undercompaction method [11,12] was adopted for reconstituting both clean sand and geofibrereinforced sand specimens. For geofibre-reinforced specimens, the geofibres were first weighed for particular geofibre content and mixed with dry sand. After mixing thoroughly, distilled and de-aired water was added to the mixture at a content to create about $50 \%$ saturation before compaction. It is important to introduce water to the mix after the geofibres so that accumulation of geofibres at one location can be minimized and a uniform distribution is achieved (Figure 4).

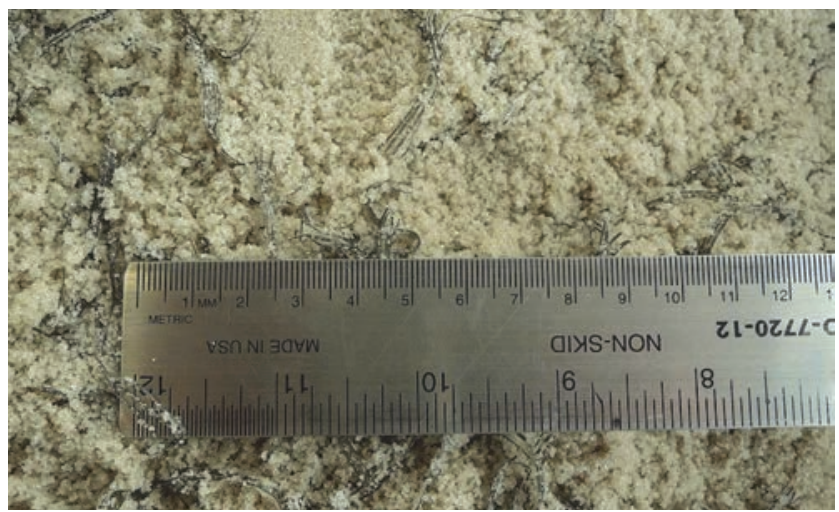

Figure 4. Photograph of sand-geofibre mixture during specimen preparation

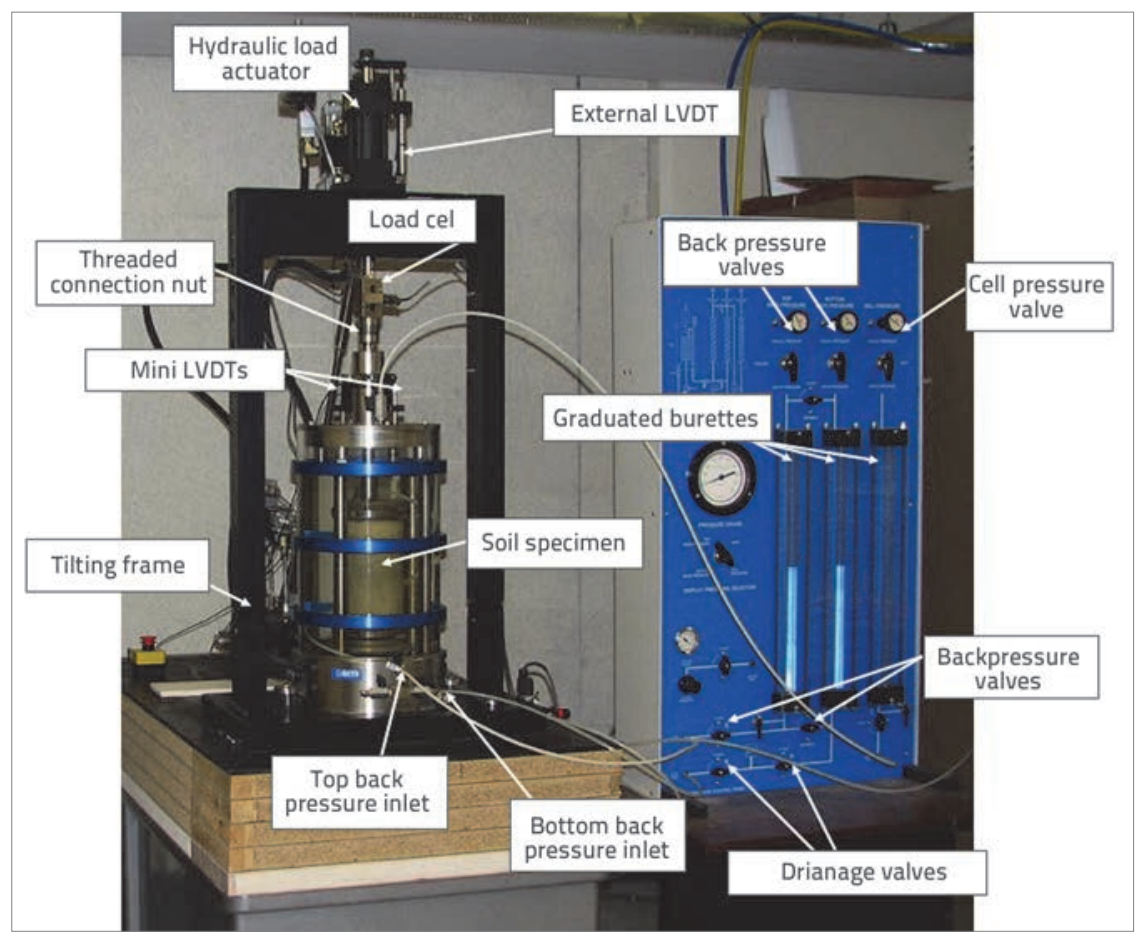

Figure 3. Photograph of testing system and set-up
Following reconstitution of the specimen, carbon dioxide $\left(\mathrm{CO}_{2}\right)$ was percolated through the sample to expedite the saturation. The $\mathrm{CO}_{2}$ displaces the air and, being much more soluble in water than air, it enables subsequent saturation steps to be carried out successfully. Then, de-aired water was flushed through the bottom drainage line of the specimen. Saturation was achieved by application of back-pressure of 100 to $200 \mathrm{kPa}$ while maintaining a constant effective stress of $30 \mathrm{kPa}$ on the specimen. Full saturation was assumed to have been achieved for Skempton's B-values of 0.96 or higher. Geofibre-reinforced specimens required long hours of back-pressure application (in some cases about 48 hours) to attain acceptable B-values. The longer time of back-pressure application in case of reinforced samples may be explained by the presence of geofibres that may have facilitated air entrapment within the soil 
sample. Once full saturation was reached, the consolidation stage was initiated. The confining effective stress was increased to the desired level and the specimen was allowed to consolidate.

\subsection{Cyclic loading and post-loading measurements}

The drainage line valves were closed prior to the application of cyclic loading to ensure undrained conditions. The axial strain was applied sinusoidally at a frequency of $0.2 \mathrm{~Hz}$. A slow loading rate was selected to ensure equilibration of pore water pressure and thus provide for more accurate pore pressure measurements [12]. Using elastic theory for fully saturated soils, the cyclic shear strain $(\gamma)$ was taken as 1.5 times $(\varepsilon)$, where $\varepsilon$ is the axial strain in an undrained triaxial testing. The test was concluded once a specific number of loading cycles was reached (i.e. $N=50$ ). To eliminate the effect of previous straining on the excess pore pressure generation, each specimen was tested at only one strain level; staged testing was avoided. The generated excess pore pressure was dissipated by permitting drainage into the backpressure burettes at the end of each test. Thus, the specimen reconsolidated at the end of test. The volume and height change of the specimen due to reconsolidation in the post-loading phase were monitored and recorded. A test matrix of the experimental program including various testing parameters is presented in Table 4.

Results of a typical cyclic triaxial test in strain-controlled mode and undrained conditions are shown in Figure 5. A reinforced

Table 4. List of tests performed

\begin{tabular}{|c|c|c|c|c|c|c|}
\hline Test & $\begin{array}{c}\text { Post-consolidation } \\
\text { relative denstity } \\
{[\%]}\end{array}$ & $\begin{array}{l}\text { B-value at the end } \\
\text { of saturation }\end{array}$ & $\begin{array}{c}\text { Cyclic shear strain } \\
\gamma[\%]\end{array}$ & $\begin{array}{l}\text { Geofibre type \& } \\
\text { content }^{*}\end{array}$ & $\begin{array}{c}\text { Confining effective } \\
\text { stress } \\
\sigma_{c}^{\prime}[k P a]\end{array}$ & $\begin{array}{l}\text { Post-consolidation } \\
\text { void ratio, e }\end{array}$ \\
\hline 1 & 52.8 & 0.96 & 0.010 & F $0.2 \%$ & 100 & 0.6244 \\
\hline 2 & 55.2 & 0.96 & 0.100 & F $0.2 \%$ & 100 & 0.6197 \\
\hline 3 & 52.1 & 0.96 & 0.300 & F $0.2 \%$ & 100 & 0.6258 \\
\hline 4 & 54.9 & 0.96 & 0.010 & F $0.5 \%$ & 100 & 0.6483 \\
\hline 5 & 58.2 & 0.97 & 0.100 & F $0.5 \%$ & 100 & 0.6404 \\
\hline 6 & 52.6 & 0.96 & 0.300 & F $0.5 \%$ & 100 & 0.6537 \\
\hline 7 & 61.1 & 0.96 & 0.010 & F $1.0 \%$ & 100 & 0.7138 \\
\hline 8 & 62.4 & 0.96 & 0.100 & F $1.0 \%$ & 100 & 0.7090 \\
\hline 9 & 61.1 & 0.96 & 0.300 & F $1.0 \%$ & 100 & 0.7138 \\
\hline 10 & 50.6 & 0.96 & 0.010 & Т $0.2 \%$ & 100 & 0.6158 \\
\hline 11 & 59.6 & 0.96 & 0.100 & Т $0.2 \%$ & 100 & 0.6047 \\
\hline 12 & 44.1 & 0.97 & 0.300 & Т $0.2 \%$ & 100 & 0.6294 \\
\hline 13 & 54.7 & 0.96 & 0.010 & Т $0.5 \%$ & 100 & 0.6406 \\
\hline 14 & 56.3 & 0.96 & 0.100 & Т $0.5 \%$ & 100 & 0.6374 \\
\hline 15 & 57.0 & 0.96 & 0.300 & Т $0.5 \%$ & 100 & 0.6361 \\
\hline 16 & 58.8 & 0.96 & 0.010 & T $1.0 \%$ & 100 & 0.6784 \\
\hline 17 & 58.4 & 0.96 & 0.100 & T $1.0 \%$ & 100 & 0.6798 \\
\hline 18 & 57.7 & 0.96 & 0.300 & T $1.0 \%$ & 100 & 0.6823 \\
\hline 19 & 51.7 & 0.98 & 0.001 & CS & 100 & 0.6249 \\
\hline 20 & 52.3 & 0.97 & 0.003 & CS & 100 & 0.6232 \\
\hline 21 & 52.5 & 0.98 & 0.005 & CS & 100 & 0.6225 \\
\hline 22 & 51.6 & 0.96 & 0.007 & CS & 100 & 0.6252 \\
\hline 23 & 51.4 & 0.97 & 0.010 & CS & 100 & 0.6258 \\
\hline 24 & 51.0 & 0.98 & 0.030 & CS & 100 & 0.6270 \\
\hline 25 & 51.4 & 0.98 & 0.060 & CS & 100 & 0.6258 \\
\hline 26 & 52.3 & 1.00 & 0.100 & CS & 100 & 0.6232 \\
\hline 27 & 51.6 & 0.98 & 0.200 & CS & 100 & 0.6252 \\
\hline 28 & 51.8 & 0.97 & 0.300 & CS & 100 & 0.6245 \\
\hline
\end{tabular}



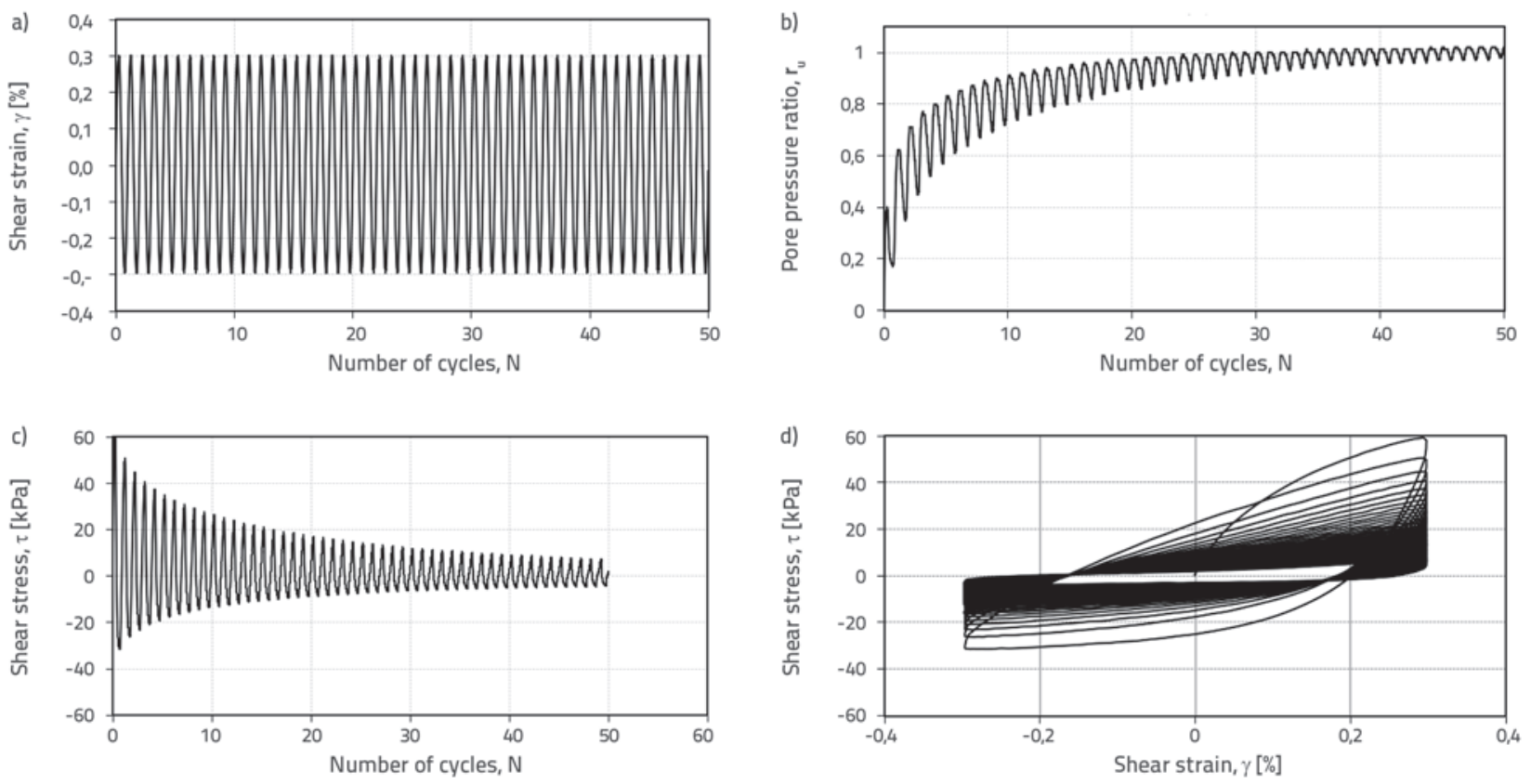

Figure 5. Typical results of a strain-controlled undrained cyclic triaxial test on saturated reinforced sand specimen $\left(\gamma=0,3 \% ; f=0,2 \mathrm{~Hz} ; \sigma_{c}{ }^{\prime}=100\right.$ $\mathrm{kPa} ; 0,5 \%$ geofibre content)

sand specimen is subjected to $0.3 \%$ shear strain for 50 loading cycles (Figure 5a). The excess pore pressure builds up and reaches a value of $r_{u}=1.0$ after about 25 loading cycles (Figure 5.b). The shear stress continuously drops with cyclic loading in response to increased excess pore pressure and decreased stiffness (Figure $5 c$ ). Shear stress versus shear strain response of the specimen is illustrated in Figure $5 d$ where degradation of stiffness can be seen clearly.

\section{Results and comparisons}

\subsection{Excess pore pressure generation of geofibre reinforced sands}

Figure 6 shows the excess pore pressure development as a function of loading cycles in clean sand specimens and in specimens reinforced with geofibres. The variable parameters for the trends presented in Figure 6 are the type of geofibre (tape vs. fibrillated), the geofibre content, and the shear strain level. The excess pore pressure ratio $\left(r_{u^{\prime}}\right.$ where $r_{u}$ $=\Delta u / \sigma_{c}{ }^{\prime} ; \Delta u$ is maximum excess pore-water pressure induced during a cycle, and $\sigma_{c}{ }^{\prime}$ is initial effective confining pressure) remained below 0.1 at the smallest shear strain level of $\gamma=$ $0.01 \%$ irrespective of the type and amount of reinforcement (Figures 6a and 6b). The upper bound was formed by the response of clean sand in case of tape type reinforcement and by the response of sample with $1 \%$ geofibre content in case of fibrillated type reinforcement. In both cases of reinforcement some overlap between responses of specimens should also be noted. A significant development of pore pressure was recorded at the shear strain level of $\gamma$ $=0.1 \%$ (Figures $6 c$ and $6 \mathrm{~d}$ ). However, the effects of the type and amount of reinforcement at this strain level are not very pronounced. The response of clean sand specimens and that of reinforced specimens appear to form a narrow band indicating very similar pore pressure, especially during the first ten loading cycles. The pore pressure ratio increased with increasing loading cycles from about 0.3 after the first cycle to around 0.9 at the end of 50 cycles. Specimens that were subjected to shear strain of $\gamma=0.3 \%$ experienced the largest pore pressures and eventually liquefied (Figures 6e and 6f). The effect of reinforcement is noticeable at this strain level. Reinforced specimens consistently developed less excess pore pressure for both types of geofibres as compared to clean sand specimens. However, it is interesting to note that different geofibre contents generated very similar excess pore pressure. The data show that the reduction in excess pore pressure due to reinforcement is slightly higher for tape type fibres. Figure 7 shows a comparison of the pore pressure generation curves of three samples subjected to the same testing conditions. The sample reinforced with tape type geofibre showed the least excess pore pressures; pore pressure ratio increased from 0.55 in the first cycle to 0.95 at $27^{\text {th }}$ cycle and the sample reached initial liquefaction $\left(r_{u}=1.0\right)$ at the $40^{\text {th }}$ cycle. Pore pressures for fibrillated type geofibre were also lower than those of the clean sand specimen, starting with an initial pore pressure ratio of 0.61 and reaching initial liquefaction at the $29^{\text {th }}$ cycle. For clean sand specimen it took seven cycles for the pore pressure ratio to exceed 0.95 and 14 cycles for initial liquefaction. 
a)

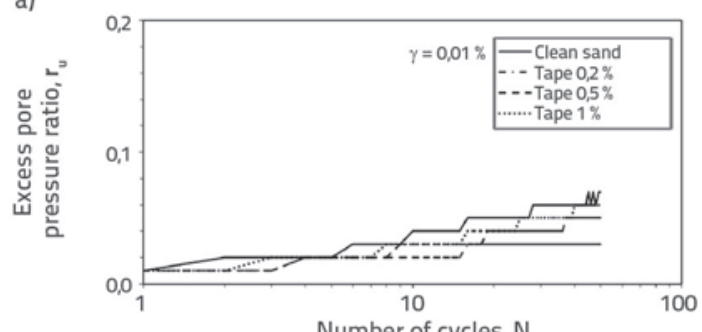

c)
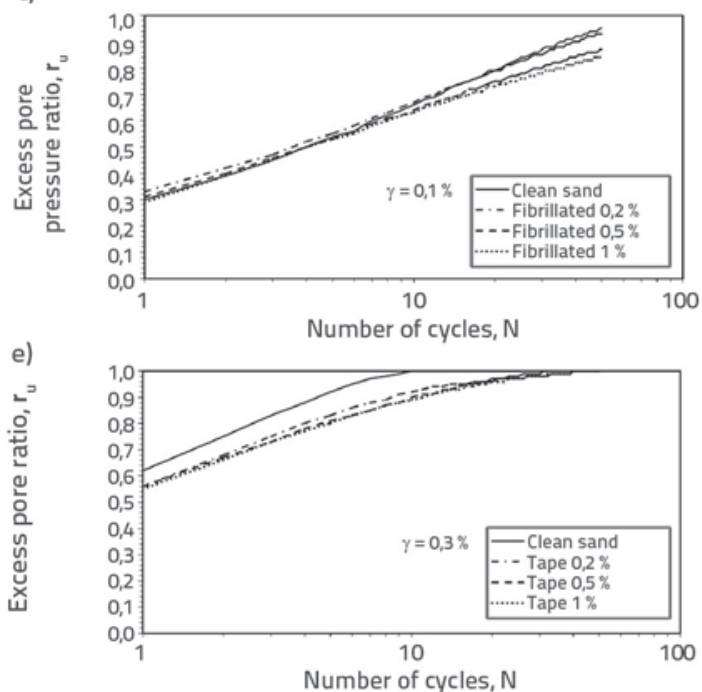

Figure 6. Excess pore (EP) pressure histories of clean sand and a) $0,01 \%$; b) $0,01 \%$; c) $0,1 \%$; d) $0,1 \%$; e) $0,3 \%$; f) $0,3 \%$

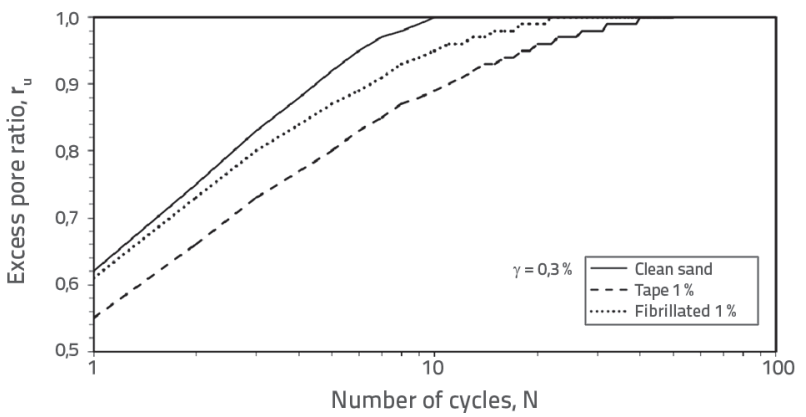

Figure 7. Comparison of excess pore pressure histories at $0.3 \%$ cyclic shear strain

The excess pore pressure generation is typically defined as a function of shear strain at N = 10 in strain-based approach for liquefaction analyses [10]. The $\mathrm{N}$ value needed for liquefaction is a function of the magnitude, $\mathrm{M}_{\mathrm{w}^{\prime}}$ of the earthquake. In case $M_{w}=7.0$ soils that liquefied in the first 10 cycles are prone to liquefaction [10,13]. Such pore pressure generation curves are shown in Figure 8. The response of specimens with fibrillated type geofibre reinforcement appears to be very similar to that of clean sand (Figure 8a). The specimens with tape type geofibre, however, show a trend of excess pore pressure, which is noticeably lower than that of clean sand (Figure 8b). The cyclic threshold shear strain $\left(\gamma_{c t}\right)$ is defined as the level of strain
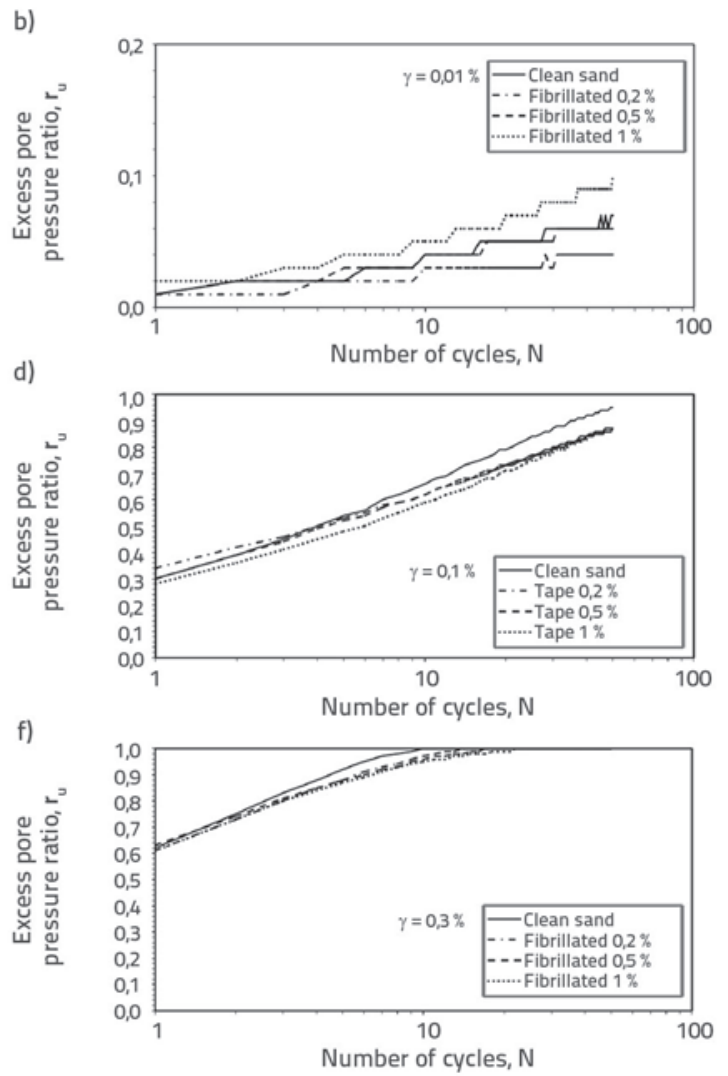

geofibre-reinforced sand, development in clean sand at:

below which little to no excess pore pressure develops [14]. It is interesting to note that the threshold shear strain $\left(\gamma_{\mathrm{ct}}\right)$ is approximately $0.01 \%$ and this level appears not to be influenced with the inclusion of either type of geofibre.

When determining liquefaction potential of soils using the strain-approach, it is important to note that cyclic strain is a function of cyclic stress calculated from peak ground acceleration and shear modulus. Therefore, when interpreting the results presented in Figure 8, caution must be exercised as stiffness and shear modulus of reinforced soils may be different from that of clean sand.

\subsection{Dissipation of pore pressure and post-loading settlement}

Post-cyclic loading settlement is typically measured by volumetric strain and is also referred to as reconsolidation settlement. The volumetric strain $\left(\varepsilon_{v}\right)$ was determined from the ratio between the post loading volume change and the post consolidation (pre-loading) volume of the specimen $\left(\varepsilon_{\mathrm{v}}=\right.$ $\Delta \mathrm{V}_{\mathrm{pt}} / \mathrm{V}_{\mathrm{p}}$ ). Volumetric strain was evaluated in terms of excess pore pressure and induced shear strain, as shown in Figures 9 and 10, respectively. The volumetric strain as a function of the excess pore pressure ratio (Figure 9) indicates that samples with higher geofibre content experienced greater 

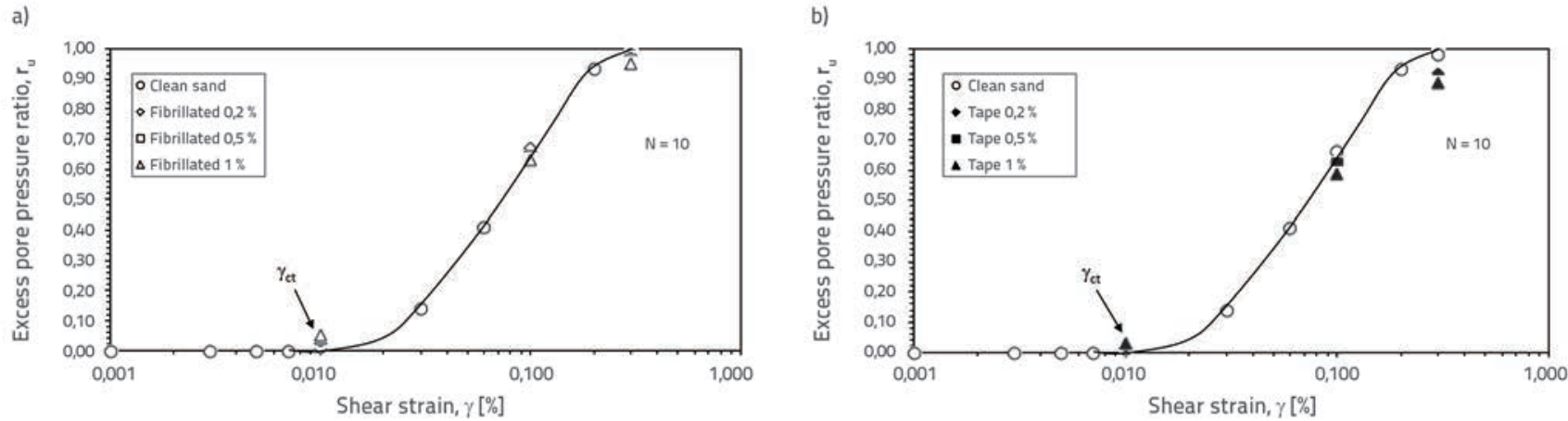

Figure 8. Pore-pressure generation curves of geofibre-reinforced sand: a) pore-pressure generation curve of sand reinforced with fibrillated type geofibre; b) pore-pressure generation curve of sand reinforced with tape type geofibre
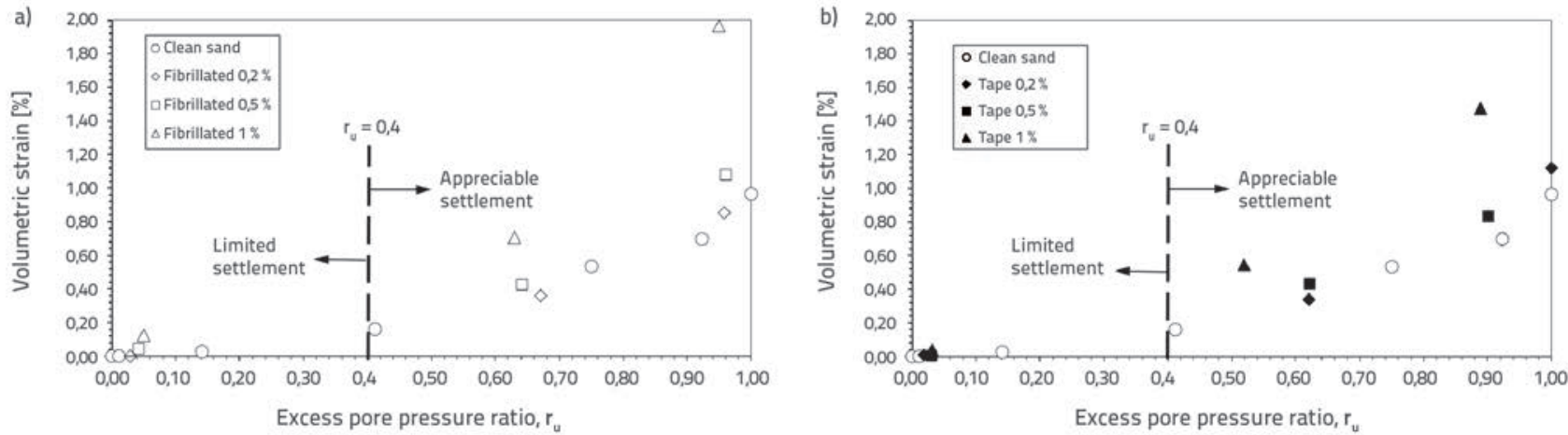

Figure 9. Post-loading volumetric strain versus pore pressure ratio: a) response of sand reinforced with fibrillated type geofibre; b) response of sand reinforced with tape type geofibre
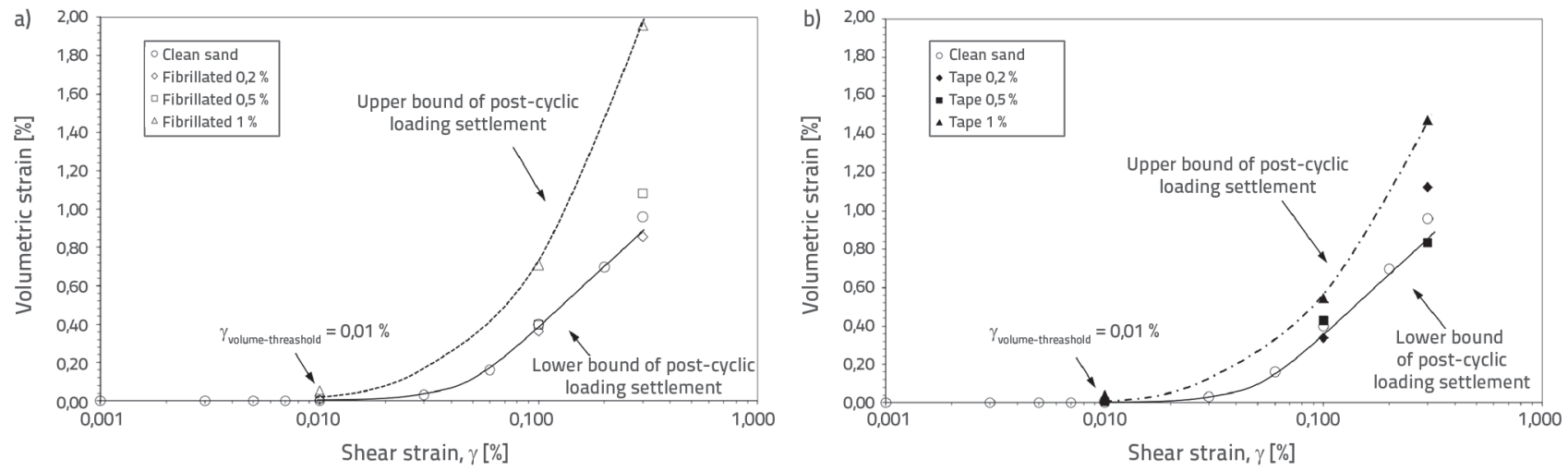

Figure 10. Post-loading volumetric strain versus cyclic shear strain: a) response of sand reinforced with fibrillated type geofibre; b) response of sand reinforced with tape type geofibre

reconsolidation volumetric strain for the same pore pressure ratio. In general, higher excess pore pressures $\left(r_{u}>0.4\right)$ resulted in noticeably larger volumetric strains, and geofibre reinforcement of both types leads to larger post-cyclic loading settlement in comparison to that of clean sand. The larger the geofibre content is, the greater the post-cyclic loading settlement becomes. The limited settlement below $r_{u}=0.4$ may be attributed to cyclic degradation characteristics of fully saturated sand in undrained conditions as reported by Vucetic and Mortezaie [15] where sand was found to undergo cyclic degradation only after $r_{u}=0.35$ is reached.
The volumetric strain as a function of cyclic shear strain is shown in Figure 10. The largest volumetric strain was consistently observed in samples with $1 \%$ geofibre content. For instance, at shear strain of $\gamma=0.1 \%$, the volumetric strain of specimens reinforced at $1 \%$ geofibre content are $0.52 \%$ and 0.64 $\%$ for tape and fibrillated type geofibres, respectively, whereas clean sand specimen experienced a volumetric strain of $0.34 \%$ at the same level of shear strain. Larger volumetric strains were measured with increasing induced shear strains. At shear strain of $0.3 \%$, the respective volumetric strains of tape and fibrillated geofibre reinforced specimens are approximately 1.5 to 2 times 
greater than that of clean sand specimen. Settlements of specimens with lower fibre content ( of $0.5 \%$ and $0.2 \%$ ) were not significantly different from the settlement observed in clean sand. At shear strain of $\gamma=0.01 \%$, the volumetric strains were negligibly small. Therefore, this level of shear strain can be considered as the volumetric threshold strain $\left(\gamma_{\text {volume-threshold }}\right)$ almost equal to that of clean sand specimens.

\section{Conclusion}

From a series of undrained, strain-controlled cyclic triaxial tests performed on saturated clean sand and sand reinforced with geofibre, it was noted that the excess pore pressure generation is influenced by the number of loading cycles, the level of induced shear strain, and the geofibre (reinforcement) content. In general, somewhat beneficial effect of reinforcement was observed in the form of slowing the generation of excess pore pressure and delaying the initial liquefaction as compared with the case of clean sand. The effect of geofibre on the development of excess pore pressure was found to become more pronounced with increasing level of induced cyclic shear strain. The tape type polypropylene geofibre was more effective than the fibrillated type in limiting generation of excess pore pressure and delaying liquefaction. Both types of geofibre were found to have little to no influence on the threshold shear strain; the widely accepted level of threshold shear strain of 0.01 $\%$ was confirmed from unreinforced and reinforced sand. The effect of pore pressure on post-loading settlement was noted; appreciable settlement of unreinforced and reinforced sand was found to occur when the excess pore pressure ratio was greater than 0.4 . For the same pore pressure and induced shear stain, geofibre-reinforced sand was found to undergo larger post-loading settlement, especially with increasing geofibre content. Post-loading settlement of the sand reinforced with fibrillated geofibre was notably larger.

\section{Acknowledgements}

The authors would gratefully like to acknowledge the support provided by U.S. DOT, Research and Innovative Technology Administration through Alaska University Transportation Center, and State of Alaska Department of Transportation \& Public Facilities under the Grant No. G3238-33650.

\section{REFERENCES}

[1] Gray, D.H., Ohashi, H.: Mechanics of fiber reinforcement in sand. Journal of Geotechnical Engineering, ASCE, 109 (1983) 3, pp. 335353.

[2] Gray, D.H., Al-Refeai, T.: Behavior of fabric versus fiber-reinforced sand. Journal of Geotechnical Engineering, ASCE, 112 (1986) 8, pp. 804-820.

[3] Maher, M.H., Gray, D.H.: Static response of sand reinforced with randomly distributed fibers. Journal of Geotechnical Engineering, ASCE, 116 (1990) 11, pp. 1661-1677.

[4] Consoli, N.C., Montardo, J.P., Prietto, P.D.M., Pasa, G.S.: Engineering behavior of a sand reinforced with plastic waste. Journal of Geotechnical and Geoenvironmental Eng., ASCE, 128 (2002) 6, pp. 462-472.

[5] Santoni, R.L., Tingle, J.S., Webster, S.L.: Stabilization of silty sand with non-traditional additives. Transportation Research Record, Paper No. 02-3756, 1787, pp. 61-70, 2002.

[6] Zornberg, J.G.: Discrete framework for limit equilibrium analysis of fibre-reinforced soil. Geotechnique, 52 (2002) 8, pp. 593-604.

[7] Hazirbaba, K., Connor, B.: The use of geofiber and synthetic fluid for stabilizing marginal soils. Proc. $8^{\text {th }}$ International Conference on the Bearing Capacity of Roads, Railways and Airfields, Champaign, IL. Bearing Capacity of Roads, Railways and Airfields 1-2, pp. 89-96., 2009.

[8] Noorany, I., Uzdavines, M.: Dynamic behavior of saturated sand reinforced with geosynthetic fabrics. Proc., Geosynthetics '89 Conf., 2 (1989), pp. 385-396.

[9] Maher, M.H., Woods, R.D.: Dynamic response of sands reinforced with randomly distributed fibers. Journal of Geotechnical Engineering, ASCE, 116 (1990) 7, pp. 1116-1131.

[10] Dobry, R., Ladd, R.S., Yokel, F.Y., Chung, R.M., Powell, D.: Prediction of pore water pressure buildup and liquefaction of sands during earthquakes by the cyclic strain method. National Bureau of Standards Building Science Series, 138 (1982), 150 pp.

[11] Ladd, R.S.: Preparing test specimens using undercompcation. Geotechnical Testing Journal, 1 (1978) 1, pp. 16-23.

[12] Hazirbaba, K., Omarow, M.: Post-cyclic loading settlement of saturated clean sand. Soil Dynamics and Earthquake Engineering, 77 (2015), pp. 337-347, https://doi.org/10.1016/j. soildyn.2015.06.007

[13] Seed, H.B., Idriss, I.M., Makdisi, F., Banerjee, N.: Representation of irregular stress time histories by equivalent uniform stress series in liquefaction analyses. EERC 75-29, Earthquake Engineering Research Center, University of California, Berkeley, 1975.

[14] Dobry, R., Swiger, W.F.: Threshold strain and cyclic behavior of cohesionless soils. Proceedings Third ASCE/EMDE Specialty Conference, Austin , TX, 9 (1979) 17-19, pp. 521-525.

[15] Vucetic, M., Mortezaie, A.: Cyclic secant shear modulus versus pore water pressure in sands at small cyclic strains. Soil Dynamics and Earthquake Engineering, 70 (2015), pp. 60-72, https://doi. org/10.1016/j.soildyn.2014.12.001 